\title{
Biełoruskije ostarbajtery. Ugon nasielenija Biełarussi na prinuditielnyje raboty w Giermaniju. Dokumienty i materiały. Kniga pierwaja 1941-1942, Minsk 1996, s.302; Kniga wtoraja 1943-1944, Minsk 1997, s. 472.
}

W latach 1996-1997 w Mińsku staraniem instytucji archiwalnych ukazał się w dwóch częściach obszerny zbiór dokumentów, przedstawiający losy ludności skierowanej z Białorusi na roboty do III Rzeszy.

Wydawcą jest Narodowe Archiwum Republiki Białoruskiej przy wsparciu finansowym Republikańskiej Fundacji Białoruskiej „Wzaimopomimanije i prymirenije”.

W zbiorze opublikowano na 774 stronach 454 dokumenty. Są to w większości dokumenty archiwalne dotąd niepublikowane. 184 dokumenty pochodzą z archiwów białoruskich, tj. ze zbiorów Narodowego Archiwum Republiki Białoruskiej (NARB), Państwowego Archiwum obwodu Mińskiego (PAOM), Białoruskiego Archiwum Dokumentacji Filmowej (BADF) i Białoruskiego Państwowego Muzeum Wielkiej Wojny Narodowej (BPMWWN). 37 dokumentów niemieckich publikowanych w zbiorze pochodzi ze zbiorów Archiwum Federalnego Niemiec (AFN). Dokumenty niemieckie publikowane są w tłumaczeniu na język rosyjski, pozostałe zaś $\mathrm{w}$ językach oryginału, tj. $\mathrm{w}$ języku rosyjskim i białoruskim. W zbiorze zamieszczono też 27 fotokopii dokumentów, w tym 2 zestawy listów osób wywiezionych na roboty oraz ulotek. Dokumentację zbioru wzbogacają też archiwalne zdjęcia.

Zbiór został starannie opracowany, zgodnie z wymogami obowiązującymi przy publikacji dokumentów z historii najnowszej. Poszczególne części poprzedzone zostały merytorycznymi wstępami (cz. I, s. 5-30 i cz. II. s. 5-10), rozbudowanymi przypisami i komentarzami oraz, co bardzo ważne, opatrzone zostały w skorowidze: imienny i nazw geograficznych. Należą się więc słowa uznania autorowi zbioru i wydawcy. Zbiór przygotował zespół: G.D.Knaćko - przewodnicząca zespołu, W. I. Adamuszko, N. A. Bondarenko, W. I. Kiryczenko, M. G. Nikitin i R. A. Czernogłazowa.

Do zbioru włączono też 166 dokumentów publikowanych już w różnych zbiorach oraz w prasie. Nie kwestionuję zasadności włączenia ich do zbioru tematycznego, chciałbym tylko zwrócić uwagę na fakt, że dokumenty zostały przedrukowywane na podstawie wcześniejszych wydań, jeszcze z okresu ZSRR. Autorzy zbioru nie uwzględnili faktu, że w ZSRR dokumenty publikowano ze znacznymi skrótami, nie zawsze zaznaczanymi w tekście i bez informacji co zawierał tekst opuszczony. Do uwagi tej skłania mnie również własne doświadczenie. Przygotowując monografię o Białostockim Zgrupowaniu Partyzanckim korzystałem m.in. ze sprawozdania dowództwa tego zgrupowania opublikowanego w zbiorze "Wsienerodnaja borba w Biełorussii protiw niemiecko-faszystskich zachwatczykow w gody Wielikoj Otieczestwiennoj Wojny" (t. II cz. 2, Minsk 1984 s. 623-630). 
Po skonfrontowaniu drukowanego tekstu z oryginałem (NARB w Minsku, zesp. 3500, r. 4. t. 289, k. 8-18) okazało się, że w drukowanym tekście ze sprawozdania usunięto informacje o trudnościach i niedostatkach w działalności zgrupowania. Czytelnik otrzymał jednostronny, zafałszowany tekst. Nie twierdzę, że jest tak również w tym przypadku. Chcę tylko zwrócić uwagę, że przedruk dokumentów z wcześniejszych wydawnictw bez informacji, że zostały one sprawdzone $\mathrm{z}$ oryginałem, może budzić wątpliwości czytelników i badaczy. Lepiej jest więc dokumenty publikować na podstawie oryginału, dodając informacje gdzie wcześniej były one już publikowane.

Z opublikowanych w zbiorze dokumentów na szczególną uwagę zasługują dyrektywy niemieckich władz w sprawie wykorzystania siły roboczej ze Wschodu oraz sprawozdania $\mathrm{z}$ ich wykonania, składane przez terenowe władze okupacyjne. Wynika z nich, że metody werbunku siły roboczej na Białorusi ewaluowały od krótkotrwałych prób jej pozyskania na zasadach dobrowolności do szeroko stosowanych drakońskich form policyjnego przymusu i terroru. Ważne miejsce w publikowanych dokumentach zajmuje opis ciężkiej sytuacji ludności kierowanej na roboty do Rzeszy i jej niewolniczego statusu w Niemczech. Część dokumentów przedstawia też udział białoruskich organizacji narodowych, działających na Białorusi za zgodą władz okupacyjnych, w werbunku ludności do pracy w Rzeszy. Szerzej prezentowane jest też w dokumentach przeciwdziałanie werbunkowi ze strony radzieckiego ruchu podziemnego i partyzanckiego. Te ostatnie kwestie prezentowane są głównie w przedrukowanych w zbiorze artykułach prasowych, odezwach-i ulotkach.

W końcowej części zbioru znajdują się też dokumenty przedstawiające problemy związane z powrotem ludności wywiezionej na roboty do Rzeszy oraz działalność władz BSRR, zmierzającą do ustalenia stanu liczbowego rozmiarów wywózki na roboty Rzeszy. Zbiór zamyka firmowana przez Radę Komisarzy Ludowych BSRR tabela, przedstawiająca liczby osób wysłanych na roboty do Rzeszy z poszczególnych obwodów z Białorusi. Wynika z niej, według danych z l. XII. 1945r., że pracowało w Niemczech 399374 mieszkańców republiki. Nie są to dane pełne, na co zwracają uwagę we wstępie autorzy zbioru.

W zbiorze jest też wzmianka o regionie białostockim. Ważnym etapem w transporcie ludności z Białorusi do Rzeszy były stacje kolejowe w Grajewie i Wołkowysku. Z Białorusi do Rzeszy na roboty trafiała również zamieszkująca tam ludność polska, tym również z regionu białostockiego.

Reasumując, należy stwierdzić, że recenzowany zbiór dokumentów w pełni zasługuje na uwagę czytelników i badaczy dziejów najnowszych, zarówno ze względu na jego duże walory poznawcze jak i naukowe. Problem wykorzystania w Rzeszy siły roboczej z obszarów okupowanych wymaga dalszych źródłowych badań i studiów.

Recenzowany zbiór dokumentów stanowi kolejny istotny krok na tej drodze.

Michal Gnatowski 